\title{
PENDAPATAN USAHATANI PEMBENIHAN LELE DUMBO DAN LELE SANGKURIANG DI DESA BABAKAN, KECAMATAN CISEENG, BOGOR
}

\author{
Putri Amaliaa ${ }^{1)}$ dan Ratna Winandi Asmarantaka ${ }^{2)}$ \\ ${ }^{1,2)}$ Departemen Agribisnis, Fakultas Ekonomi dan Manajemen, Institut Pertanian Bogor \\ 1)amaliaputri16@gmail.com
}

\begin{abstract}
Catfish is one of the nine potential leading commodities in Indonesia. The biggest demand of the fish reaches 250 tons a day in Java and this makes the fish breeding business very important. One of the catfish breeding areas is Babakan Seeng, Bogor District. There are two catfish verieties, i.e Dumbo, which is cultivated in Pokdakan Jumbo Lestari and Sangkuriang in Pokdakan kubang sejahtera. The breeding system of those varieties is different: stocking density of 10000 juveniles per $300 \mathrm{~m}^{2}$ for Dumbo and 20000 juveniles per $300 \mathrm{~m}^{2}$ for Sangkuriang, due to the bigger egg hatching expectation; i.e $90 \%$. The research showed that the income of Dumbo catfish farm was Rp 7544 531, while that of the sangkuriang catfish farm was only Rp 3857 981. $R / C$ ratio of Dumbo catfish farm was 1.49 and $R / C$ ratio of Sangkuriang catfish farm was 1.16. Chi-squares analysis also proves that the difference the way aquaculture can effect farm income. This proves that Dumbo catfish farm is more profitable compared to Sangkuriang farm. Sangkuriang catfish hatchery can be more profitable when the stocking density is lessened.
\end{abstract}

Keyword(s): Catfish hatchery, Solid stocking, Income, $R / C$ ratio, Chi-Square

\begin{abstract}
ABSTRAK
Lele adalah salah satu komoditas potensial dari sembilan komoditas unggulan di Indonesia. Permintaan akan kebutuhan lele terbesar pun mencapai 250 ton per hari di wilayah Jawa yang menyebabkan peranan pembenihan menjadi sangat penting. Salah satu sentra pembenihan ikan lele terdapat di Desa Babakan, Kecamatan Ciseeng, Bogor. Terdapat dua varietas yang dibudidayakan yaitu lele dumbo di Pokdakan Jumbo Lestari dan lele sangkuriang di Pokdakan Kubang Sejahtera. Cara pembenihan kedua varietas tersebut berbeda, lele dumbo menggunakan padat tebar 10.000 benih per $300 \mathrm{~m}^{2}$ sementara lele sangkuriang 20.000 benih per $300 \mathrm{~m}^{2}$ dikarenakan pembenih lele sangkuriang menganggap derajat penetasan telur $90 \%$ yang lebih besar dibandingkan lele dumbo sehingga semakin banyak benih yang ditebar semakin banyak output yang dihasilkan. Setelah dilakukan penelitian mengenai pendapatan usahatani di kedua pokdakan tersebut, pendapatan lele dumbo sebesar Rp 7544531 sementara lele sangkuriang hanya mencapai Rp 3857 981. Sementara untuk R/C rasio lele dumbo mencapai 1.49 dan lele sangkuriang mencapai 1.16. Analisis Chi Square juga membuktikan bahwa perbedaan cara budidaya dapat mempengaruhi pendapatan yang diperoleh dengan hasil $\mathrm{x}^{2}$ hitung sebesar 35,0972 yang lebih besar dari $x^{2}$ tabel sebesar 23.685 Hal ini membuktikan bahwa lele dumbo lebih menguntungkan dibandingkan dengan lele sangkuriang. Pembenihan lele sangkuriang dapat lebih menguntungkan jika penanganan padat tebar benih dikurangi.
\end{abstract}

Kata Kunci: Pembenihan Lele, Padat Tebar, Pendapatan, R/C rasio, Chi-Square 


\section{Latar Belakang}

\section{PENDAHULUAN}

Perikanan merupakan salah satu sektor yang dapat meningkatkan kesejahteraan masyarakat Indonesia. Sektor perikanan dikelompokan ke dalam dua kategori yaitu perikanan tangkap dan perikanan budidaya. Risiko perikanan budidaya lebih rendah dibandingkan dengan perikanan tangkap yang dibuktikan dengan laju produksi perikanan budidaya yang mencapai $30.82 \%$ pada tahun 2009 sampai dengan 2013, sementara pada perikanan tangkap hanya mampu mencapai 3.52\% (Kementerian Kelautan dan Perikanan, 2013). Ikan lele merupakan salah satu komoditas potensial dari Sembilan komoditas unggulan di Indonesia.

Produksi ikan lele di Indonesia setiap tahunnya mengalami peningkatan. Berbeda dengan produksi komoditas perikanan budidaya mas dan bawal yang cenderung berubah-ubah. Dapat dilihat juga bahwa produksi ikan lele mengalahkan produksi komoditas perikanan budidaya lainnya. Hal tersebut mengindikasi bahwa jumlah produksi ikan lele yang meningkat merupakan dampak dari adanya peningkatan permintaan akan produk tersebut (Lampiran 1).

Menurut Jaja et. al (2013) menyatakan bahwa ikan lele menjadi komoditas yang disukai banyak orang yang sebelumnya hanya dianggap sebagai ikan murahan dan hanya dikonsumsi oleh pembudidaya. Kini ikan lele menjadi komoditas yang unggul sehingga dapat dijadikan peluang bisnis. Di samping itu, dari sisi periode pertumbuhannya yang cepat, tolerir terhadap suhu, mudah dibudidayakan, tingkat konversi pakan yang baik dan mudah dalam mencari pasar dengan harga yang kompetitif (Alawode O.O. dan A.O. Jinad 2014).

Selain itu, Olagunju et al. (2007) dalam penelitiannya di Nigeria menyatakan bahwa ikan lele juga memiliki pangsa pasar yang lebih luas dibandingkan dengan ikan nila. Hal tersebut dapat terwujud bila pembudidaya mampu mengelola manajemen pembudidayaan dengan baik dari sisi kecepatan mengadopsi penggunaan bibit unggul dan teknologi, pemberian pakan yang intensif dan tercapainya tingkat efisiensi teknis di tingkat pembudidaya (Ugwumba COA 2011).

Menurut Dinas Perikanan Provinsi Jawa Barat (2012) menyatakan bahwa Kabupaten Bogor merupakan salah satu pusat sentra produksi yang berkontribusi sebesar $27.4 \%$ dari jumlah produksi di Jawa Barat. Jawa barat, yang memiliki produksi tertinggi sebesar 197.783 ton yang didalamnya terdapat peranan dari Bogor dan Jakarta pun masih belum mampu untuk memenuhi permintaan konsumen akan komoditas lele.

Hal ini menyebabkan sektor pembenihan menjadi sektor yang sangat penting untuk meningkatkan produksi lele. Adapun sentra budidaya pembenihan lele yaitu di Desa Babakan, Kecamatan Ciseeng, Bogor yang memiliki dua jenis ikan lele yang dibudidayakan yaitu lele sangkuriang dan lele dumbo. Menurut Mahyuddin (2008) menyatakan bahwa lele sangkuriang lebih unggul dibandingkan dengan lele dumbo (Lampiran 2). 


\section{Perumusan Masalah}

Lele, satu dari Sembilan komoditas unggulan di sektor perikanan budidaya. Kebutuhan lele konsumsi mengalami peningkataan dari tahun ke tahun yang tertera pada Lampiran 3. Hal ini menyebabkan pembudidaya lele perlu meningkatkan produksinya sehingga dapat memenuhi keinginan konsumen lele yang menyebabkan sektor pembenihan menjadi sektor yang sangat penting untuk meningkatkan produksi lele. Salah satu sentra penghasil lele yaitu Desa Babakan, Kecamatan Ciseeng, Kabupaten Bogor.

Desa Babakan memiliki dua varietas lele yang dibudidayakan yaitu lele dumbo di Pokdakan Jumbo Lestari dan lele sangkuriang di Pokdakan Kubang Sejahtera. Cara pembudidayaan di kedua pokdakan berbeda satu sama lain. Padat tebar yang digunakan di Pokdakan Jumbo Lestari yaitu 10.000 per $300 \mathrm{~m} 2$, sementara untuk padat tebar di Pokdakan Sangkuriang sebesar 20.000 per $300 \mathrm{~m} 2$ dikarenakan lele sangkuriang yang memiliki derajat penetasan sebesar $90 \%$ sehingga pembudidaya menduga semakin banyak benih yang ditebar semakin banyak pula output lele yang dihasilkan.

Padahal menurut SNI Nomor 01.6484.4-2000, padat tebar yang sebaiknya digunakan yaitu berkisar antara 10.000 sampai dengan 15.000 per $300 \mathrm{~m}^{2}$. Tenaya (2010) juga menyatakan benih dapat berpengaruh positif terhadap produktivitas lele sehingga pemilihan padat tebar menjadi sangat penting untuk dipilih oleh pembudidaya. Semakin banyak benih yang ditebar, semakin banyak pula pakan yang diberikan.
Padahal menurut Afrianto dan Evi (2005), besarnya biaya yang harus dikeluarkan untuk pengadaan pakan terutama untuk budidaya intensif dapat mencapai $60 \%$ dari biaya produksi. Pemberian pakan juga harus dikontrol dengan baik karena jika pembenih memberikan pakan terlalu banyak dapat menimbulkan penyakit pada ikan lele, sementara jika pemberian pakan kurang menyebabkan lele yang ukurannya besar akan memakan lele yang ukurannya lebih kecil (kanibal).

Di samping itu, intensitas Pokdakan Jumbo Lestari dalam mengikuti penyuluhan perikanan sebanyak dua kali dalam sebulan, berbeda hal nya dengan Pokdakan Kubang Sejahtera yang jarang mengikuti penyuluhan perikanan. Dari permasalahan tersebut, maka diperlukan analisis pendapatan usahatani untuk mengetahui dampak dari cara pembudidayaan yang berbeda terhadap pendapatan usahatani lele dumbo dan lele sangkuriang. Pendapatan adalah selisih antara total penerimaan dan total pengeluaran (Soekartawi, 2003).

Namun besarnya pendapatan tidak selalu menunjukan efisiensi yang tinggi, oleh karena ini analisis pendapatan selalu diikuti dengan pengukuran efisiensi yang menggunakan perbandingan (nisbah) antara penerimaan dan biaya yang merupakan keuntungan relatif dari suatu kegiatan usahatani berdasarkan perhitungan finansial disebut sebagai $\mathrm{R} / \mathrm{C}$ rasio.

Dari uraian tersebut, maka pertanyaan penelitian yang ingin dipecahkan dalam penelitian ini yaitu:

1. Bagaimana perbandingan struktur penerimaan dan biaya usahatani 
pembenihan lele dumbo dan lele sangkuriang di Desa Babakan?

2. Bagaimana perbandingan tingkat pendapatan usahatani pembenihan lele dumbo dan lele sangkuriang di Desa Babakan?

\section{Tujuan Penelitian}

Berdasarkan latar belakang dan permasalahan maka tujuan penelitian adalah: 1. Menganalisis perbandingan struktur penerimaan dan biaya dari usahatani pembenihan lele dumbo dan lele sangkuriang di Desa Babakan

2. Menganalisis perbandingan tingkat pendapatan usahatani pembenihan lele dumbo dan lele sangkuriang di Desa Babakan

\section{KERANGKA PEMIKIRAN Biaya Usahatani}

Total Biaya usahatani adalah nilai semua input yang habis terpakai atau dikeluarkan di dalam produksi. Menurut Soekartawi (2003) Biaya usahatani dapat dibagi menjadi dua bagian yaitu Biaya tunai yang terdiri dari biaya tetap dan variabel yang dibayar tunai. Biaya tetap tidak tergantung pada besar kecilnya produksi seperti pajak tanah, sewa tanah, penyusutan alat-alat bangunan pertanian dan bunga pinjaman. Biaya variabel yang berhubungan langsung dengan jumlah produksi yaitu pengeluaran untuk bibit, pupuk, obat-obatan dan biaya tenaga kerja. Biaya tetap dan variabel merupakan bentuk struktur biaya usahatani. Biaya tunai pada pembenihan lele dumbo dan sangkuriang yaitu benih (ekor), pakan (sak), pupuk (kg), obat-obatan, tenaga kerja luar keluarga (HOK).
Biaya diperhitungkan atau biaya tidak tunai yaitu pengeluaran secara tidak tunai oleh petani berupa faktor produksi yang digunakan oleh petani tanpa mengeluarkan uang tunai seperti sewa lahan yang diperhitungkan atas lahan milik sendiri yang digunakan untuk mengelola pembenihan lele, penggunaan tenaga kerja keluarga, penggunaan benih dari hasil produksi dan penyusutan dari sarana produksi investasi.

\section{Penerimaan Usahatani}

Menurut Suratiyah (2006), penerimaan usahatani adalah seluruh pendapatan yang diperoleh dari usahatani selama satu periode yang diperhitungkan dari hasil penjualan atau penaksiran kembali. Penerimaan terbagi menjadi dua kategori yaitu penerimaan tunai dan penerimaan total.

Penerimaan tunai yaitu nilai uang yang diterima dari penjualan pokok usahatani. Sedangkan penerimaan tidak tunai merupakan nilai hasil produk yang tidak dijual, tetapi dikonsumsi sendiri, disimpan sebagai persediaan atau aset petani sehingga tidak memberika hasil dalam bentuk uang. Penerimaan tunai tidak mencakup pinjaman uang yang diperlukan untuk keperluan usahatani dan tidak mencakup yang berbentuk benda. Oleh karena itu, nilai produk usahatani yang dikonsumsi tidak dihitung sebagai penerimaan tunai. Sumber penerimaan usahatani diperoleh dari pendapatan hasil, nilai hasil yang dikonsumsi keluarga, menyewakan, dan penjualan unsur-unsur produksi, subsidi pemerintah dan penambahan nilai inventarisasi (Hernanto 1996) 


\section{Teori Produksi}

Menurut Salvator (2005) produksi merupakan seluruh aktivitas yang terlibat dalam memproduksi barang dan jasa, dari meminjam untuk membangun atau melakukan ekspansi fasilitas produksi, merekrut tenaga kerja, membeli bahan mentah, menjalankan pengendalian mutu, akuntansi biaya, dan lain-lain. Hubungan fisik output dengan faktor produksi input disebut sebagai factor relationship (Hanafie 2010).

Penambahan input produksi mengikuti hukum The law of diminishing marginal returns merupakan dasar dalam ekonomi produksi yang dapat terjadi jika jumlah input variabel ditambah penggunaannya, maka output yang dihasilkan meningkat tetapi setelah mencapai titik tertentu penambahan output semakin lama semakin berkurang (Debertin 2002).

Selanjutnya menurut Beattie dan Taylor (1985) terdapat beberapa asumsi dasar pada fungsi produksi, yaitu: (1) Kegiatan produksi perusahaan diatur sedemikian rupa sehingga produksi dalam satu periode waktu bersifat independen; (2) Semua input dan output bersifat homogen; (3) Fungsi produksi dapat diturunkan dua kali secara kontinu; (4) Tidak terdapat batasan ketersediaan input; dan (5) Tujuan perusahaan adalah memaksimalkan keuntungan atau meminimalkan biaya untuk tingkat output tertentu.

\section{Konsep Pendapatan Usahatani}

Besarnya pendapatan yang diperoleh dalam mengelola usaha dapat dijadikan indikator dari berhasilnya suatu usaha. Pendapatan diukur dari nilai jasa yang diterima dari pengunaan input tertentu. Adapun perhitungan pendapatan usahatani menurut Soekartawi (2003) yaitu:

$$
\begin{gathered}
\mathrm{I}_{\text {tunai }}=\mathrm{NP}-\mathrm{BT} \\
\mathrm{I}_{\text {total }}=\mathrm{NP}-(\mathrm{BT}+\mathrm{BD})
\end{gathered}
$$

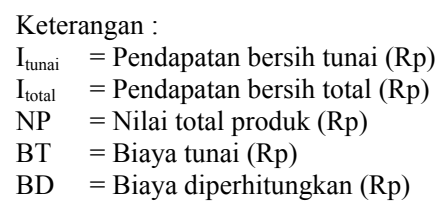

Menurut Suratiyah (2006), menjelaskan bahwa faktor-faktor yang mempengaruhi pendapatan usahatani dibagi menjadi dua yaitu faktor-faktor intern dan ekstern. Faktor intern usahatani yang mempengaruhi pendapatan usahatani yaitu kesuburan lahan, luas lahan garapan, ketersediaan tenaga kerja, ketersediaan modal dalam usahatani, penggunaan input teknologi, pola tanam, lokasi tanaman, fragmentasi lahan, status penguasaan lahan, cara pemasaran output, efisiensi penggunaan input dan tingkat pengetahuan maupun keterampilan petani dan tenaga kerja.

Adapun yang mempengaruhi faktor ekstern usahatani diantaranya sarana transportasi, sistem tataniaga, penemuan teknologi baru, fasilitas irigasi, tingkat harga output dan input, ketersediaan lembaga perkreditan, adat istiadat masyarakat dan kebijakan pemerintah.

\section{Imbangan Penerimaan dan Biaya $(\mathrm{R} / \mathrm{C}$ Rasio)}

Perbandingan (nisbah) antara penerimaan dan biaya yang merupakan keuntungan relatif dari suatu kegiatan usahatani berdasarkan perhitungan finansial disebut sebagai $\mathrm{R} / \mathrm{C}$ ratio 
dimana pendapatan yang besar tidak selalu menunjukkan efisiensi yang tinggi. Oleh karena itu, analisa pendapatan selalu diikuti dengan pengukuran efisiensi.

Salah satu ukuran efisiensi adalah penerimaan untuk rupiah yang dikeluarkan atau Revenue Cost Ratio. Apabila $\mathrm{R} / \mathrm{C}$ rasio $>1$ menyebabkan penerimaan yang diperoleh lebih besar dari unit biaya yang dikeluarkan untuk memperoleh penerimaan tersebut. Sedangkan, R/C rasio $<1$ menunjukan bahwa tiap unit biaya yang dikeluarkan akan lebih besar dari penerimaan yang diperoleh.

\section{METODE PENELITIAN}

\section{Lokasi dan Waktu Penelitian}

Penelitian ini dilakukan di Desa Babakan, Kecamatan Ciseeng, Kabupaten Bogor khususnya di Pokdakan Jumbo Lestari dan Pokdakan Kubang Sejahtera. Lokasi penelitian dipilih secara sengaja (purposive sampling) dengan pertimbangan bahwa lokasi tersebut merupakan salah satu sentra produksi benih lele. Penelitian dilaksanakan pada bulan Desember 2013 hingga Januari 2014.

\section{Jenis dan Sumber Data}

Data yang digunakan yaitu data primer dan data sekunder. Data primer diperoleh melalui wawancara langsung dan pengisian kuesioner yang diajukan kepada responden terkait dengan pendapatan usahatani pembenihan lele dumbo dan lele sangkuriang. Data sekunder dikumpulkan dari literatureliterature yang relevan seperti buku, jurnal penelitian, internet, Badan Pelaksana Penyuluhan Pertanian Perikanan dan
Kehutanan (BP3K) Wilayah Ciseeng Kabupaten Bogor, Dinas Peternakan dan Perikanan Kabupaten Bogor, BPS, KKP dan Perpustakaan.

\section{Metode Pengumpulan Data}

Metode pengumpulan data primer dilakukan melalui wawancara langsung. Penentuan responden petani dilakukan dengan metode sensus berdasarkan informasi yang diperoleh dari perangkat desa, Dinas Peternakan dan perikanan Kabupaten Bogor, BP3K, dan UPT sehingga diperoleh 15 pembenih dari Pokdakan Jumbo Lestari dan 5 pembenih dari Pokdakan Kubang Sejahtera. Sedangkan data sekunder, teknik pengumpulan data dilakukan melalui penelusuran pustaka dan studi literature.

\section{Metode Analisis Data}

Metode analisis data yang digunakan dalam penelitian ini adalah metode penelitian kualitatif dan kuantitatif dengan menggunakan software komputer Microsoft Excel 2010. Data yang bersifat kualitatif dianalisis untuk menjelaskan gambaran usahatani pembenihan lele baik dumbo dan sangkuriang. Data kuantitatif menganalisis perhitungan biaya usahatani berupa biaya tunai dan diperhitungkan, penerimaan, pendapatan, $\mathrm{R} / \mathrm{C}$ rasio dan analsis Chi-Square. Adapun rumus untuk mencari $\mathrm{R} / \mathrm{C}$ rasio yaitu :

$$
\begin{gathered}
\mathrm{R} / \mathrm{C} \text { rasio atas biaya tunai }= \\
\mathrm{TR} / \text { biaya tunai } \\
\mathrm{R} / \mathrm{C} \text { rasio atas biaya total }= \\
\mathrm{TR} / \mathrm{TC}
\end{gathered}
$$

Keterangan :

$\mathrm{TR}=$ Total Revenue $(\mathrm{Rp}) ; \mathrm{TC}=$ Total Cost $(\mathrm{Rp})$ 
Sementara, untuk analisis uji beda chi-square menggunakan langkahlangkah pengujian hipotesis satu varians diantaranya menentukan formulasi hipotesis, menentukan taraf nyata dan nilai $\mathrm{X}^{2}$ ditentukan dengan derajat bebas $(\mathrm{db})=\mathrm{n}-1$ taraf nyata yang digunakan untuk bidang sosial yaitu $10 \%$, menentukan kriteria pengujian, menentukan nilai statistik uji dan membuat kesimpulan yakni menyimpulkan Ho diterima atau ditolak. Adapun rumus dari uji beda chi-square yaitu :

$$
X^{2}=\frac{(n-1) S^{2}}{\sigma_{0}^{2}}
$$

Keterangan :

$\mathrm{N}=$ jumlah responden

$\mathrm{S}$ = simpangan baku dumbo

$\sigma_{0}=$ simpangan baku sangkuriang

\section{GAMBARAN UMUM}

Desa Babakan, salah satu kawasan minapolitan dengan peruntukan luas lahan untuk empang mencapai 36.58\% atau setara dengan $167000 \mathrm{Ha}$. Mata pencaharian pokok masyarakat Desa Babakan mayoritas adalah pedagang dengan tingkat pendidikan paling banyak yaitu tamatan SD. Pembenihan lele di Desa Babakan dilakukan oleh dua pokdakan yaitu Jumbo Lestari berjumlah 15 orang dan Kubang Sejahtera berjumlah 5 orang. Kedua pokdakan ratarata berumur 30 sampai dengan 50 tahun, mayoritas berpendidikan tamatan SD, dengan luas lahan masing-masing pokdakan kurang dari 0,5 Ha dengan UPR Jumbo Lestari rata-rata luas lahan yaitu 0,489 Ha dan Kubang Sejahtera 0,46 Ha.
Pengalaman kedua pokdakan dalam membenih lele rata-rata diantara 20 sampai dengan 30 tahun. Padat tebar antara kedua pokdakan berbeda yaitu untuk UPR Jumbo Lestari mayoritas menggunakan padat tebar 10.000 ekor per petakan sementara Kubang Sejahtera menggunakan padat tebar 20.000 ekor per petakan.

Budidaya pembenihan lele antara dumbo dan sangkuriang secara keseluruhan adalah sama. Adapun tahapantahapan pembudidayaannya yaitu dimulai dari persiapan kolam, pemupukan, pengelolaan air, penebaran benih, pemeliharaan, dan pemanenan. Pemanenan yang dilakukan oleh keduanya dimulai dari ukuran 5-6 cm, 7-8 cm, 9-10 cm sampai 11-12 cm dengan harga yang berbeda-beda di setiap ukuran

\section{PENERIMAAN USAHATANI PEMBENIHAN LELE}

Penerimaan total pembenihan lele dumbo sebesar Rp 26358185 per Ha dan lele sangkuriang sebesar Rp 27916349 per Ha untuk semua ukuran baik 5-6 cm, 7-8 cm, 9-10 cm dan 11-12 cm. Proporsi penerimaan benih lele terbanyak untuk pembenihan lele dumbo berada pada ukuran $7-8 \mathrm{~cm}$ sebesar $29.79 \%$ dari total penerimaan, sementara untuk pembenihan lele sangkuriang proporsi penerimaan terbanyak diperoleh pada benih ukuran $11-12 \mathrm{~cm}$ sebesar $33.58 \%$ dari total penerimaan. Sehingga dapat disimpulkan bahwa penerimaan total per $\mathrm{Ha}$ pembenihan lele sangkuriang lebih besar dibandingkan lele dumbo dengan permintaan lele sangkuriang tertinggi berada pada ukuran 11-12 cm, sedangkan untuk 
permintaan lele dumbo tertinggi berada pada rukuran $7-8 \mathrm{~cm}$.

\section{BIAYA USAHATANI PEMBENIHAN LELE}

Biaya usahatani terdiri dari biaya tunai dan biaya non tunai. Jumlah total biaya pembenihan lele dumbo per hektar nya sebesar Rp 18813654 sementara untuk total biaya pembenihan lele sangkuriang per hektarnya sebesar Rp 24 058 368. Biaya usahatani lele dumbo lebih rendah dibandingkan lele sangkuriang dikarenakan penggunaan padat tebar pada lele sangkuriang lebih banyak dibandingkan dengan lele dumbo sehingga kebutuhan input untuk lele sangkuriang pun lebih banyak.

Biaya tunai merupakan biaya yang dikeluarkan secara tunai dalam aktivitas bisnis. Biaya tunai pembenihan lele dumbo sebesar Rp 17600741 per hektar sedangkan pembenihan lele sangkuriang mengeluarkan biaya tunai sebesar Rp 22 775115 per hektar. Biaya tunai tersebut digunakan untuk penggunaan saprotan yang terdiri dari biaya benih dan biaya pakan, biaya pemeliharaan (booster, plastic, garam, packing, karet), biaya transportasi, biaya komunikasi, pajak lahan dan biaya tenaga kerja luar keluarga.

Alokasi biaya tunai yang terbesar berada pada penggunaan benih ukuran 1$2 \mathrm{~cm}$ yaitu sebesar $47.03 \%$ dari total biaya tunai pembenihan lele dumbo, begitu pula dengan proporsi biaya benih pada lele sangkuriang yaitu sebesar 52.79\% dari total biaya tunai. Selanjutnya biaya terbesar setelah biaya benih yaitu total biaya pakan berupa pakan cacing sutera, pelet tepung, pelet F99 yang mencapai lebih dari 20\% dari biaya tunai baik untuk pembenihan lele dumbo maupun lele sangkuriang.

Sehingga dapat disimpulkan bahwa biaya benih dan biaya pakan menjadi input yang yang paling berpengaruh dalam aktivitas produksi. Bila terjadi kenaikan harga, ketidaktepatan penggunaan jumlah benih dan pakan akan sangat mempengaruhi jumlah output yang dihasilkan oleh pembenih baik bagi pembenih lele dumbo maupun lele sangkuriang.

Sementara, untuk biaya non tunai atau biaya diperhitungkan pada pembenihan lele dumbo sebesar per hektar sebesar Rp 1212913 sedangkan untuk pembenihan lele sangkuriang sebesar Rp 1283253 per hektar. Biaya non tunai terdiri dari biaya penyusutan, biaya sewa lahan, dan biaya tenaga kerja luar keluarga.

Proporsi biaya tenaga kerja dalam keluarga di kedua sistem pembenihan lebih besar dibandingkan dengan untuk biaya penyusutan dan sewa lahan yaitu $68.74 \%$ dari total biaya non tunai untuk pembenihan lele dumbo dan $71.19 \%$ dari total biaya non tunai untuk pembenihan lele sangkuriang.

Namun, penggunaan tenaga kerja luar keluarga (TKLK) lebih banyak dibandingkan dengan tenaga kerja dalam keluarga (TKDK) di kedua system pembenihan. Pembenihan lele dumbo menggunakan TKLK sebesar 49.66 HOK yang lebih besar dibandingkan dengan TKDK yang hanya 20.84 HOK. Begitu pula dengan pembenihan lele sangkuriang yang menggunakan TKLK 
sebesar 50.5 HOK yang lebih besar dibandingkan dengan TKDK yang hanya 22.84 HOK (Lampiran 4).

Sehingga penggunaan tenaga kerja luas keluarga lebih berpengaruh terhadap pembudidayaan lele baik dumbo maupun sangkuriang dibandingkan dengan penggunaan tenaga kerja luar keluarga.

\section{PENDAPATAN USAHATANI PEMBENIHAN LELE}

Metode yang digunakan dalam analisis ini yaitu membandingkan antara pendapatan usahatani pembenihan lele dumbo dengan pembenihan lele sangkuriang. Analisis pendapatan usahatani ini menggunakan hasil perhitungan ratarata dari responden pembenih lele dumbo dan sangkuriang dengan luas lahan satu hektar yang dihitung pada periode bulan Desember sampai dengan Januari dengan empat kali produksi yaitu pada benih ukuran 5-6 cm, 7-8 cm, 9-10 cm dan 11$12 \mathrm{~cm}$.

Pendapatan usahatani pembenihan lele dibagi menjadi pendapatan usahatani atas biaya tunai dan pendapatan usahatani atas biaya total. Pendapatan atas biaya tunai yang diperoleh dari penerimaan total dikurangi dengan total biaya tunai untuk pembenih dumbo sebesar Rp 9808 954 dan untuk pembenih sangkuriang sebesar Rp 6194952.

Pendapatan atas biaya total yang diperoleh dari pengurangan penerimaan total dengan biaya total untuk benih dumbo sebesar Rp 8596041 sementara untuk benih sangkuriang Rp 4911699 (Lampiran 3).

Pada dasarnya usahatani pembenihan lele dumbo maupun lele sangkuriang sama-sama mendatangkan keuntungan, namun dilihat dari sisi pendapatan baik tunai atapun non tunai pembenihan lele dumbo memberikan pendapatan yang lebih besar dibandingkan pembenihan lele sangkuriang di Desa Babakan, Kecamatan Ciseeng, Bogor.

\section{IMBANGAN BIAYA DAN PENERIMAAN (R/C RASIO)}

Analisis $\mathrm{R} / \mathrm{C}$ rasio merupakan perhitungan yang membagi nilai penerimaan dengan biaya usahatani. $\mathrm{R} / \mathrm{C}$ rasio terbagi menjadi dua yaitu $\mathrm{R} / \mathrm{C}$ rasio tunai dan $\mathrm{R} / \mathrm{C}$ rasio total. $\mathrm{R} / \mathrm{C}$ rasio tunai membagi penerimaan dengan biaya tunai, sedangkan $\mathrm{R} / \mathrm{C}$ rasio total membagi penerimaan total dengan total biaya.

Adapun $\mathrm{R} / \mathrm{C}$ rasio tunai untuk pembenihan lele dumbo sebesar 1.49 yang menjelaskan bahwa tiap 1 rupiah dari biaya tunai yang dikeluarkan akan memperoleh penerimaan sebesar Rp 1.49 yang menyebabkan pendapatan tunai yang diterima adalah sebesar Rp 0.49 per satuan input biaya tunai yang dikeluarkan.

Sementara untuk pembenihan lele sangkuriang memperoleh $\mathrm{R} / \mathrm{C}$ rasio tunai sebesar 1.23 sehingga pendapatan tunai yang diperoleh adalah sebesar Rp 0.23 per satuan input biaya tunai. Hal ini mengindikasikan bahwa dari sisi $\mathrm{R} / \mathrm{C}$ rasio tunai memang pembenihan lele sangkuriang sudah efisien karena nilai $\mathrm{R} / \mathrm{C}$ rasionya lebih dari 1 , akan tetapi pembenihan lele dumbo dilihat dari $\mathrm{R} / \mathrm{C}$ rasionya lebih menguntungkan dibandingkan dengan pembenihan lele sangkuriang dikarenakan pendapatan 
tunai yang diperoleh pembenih lebih besar.

Di samping itu, dari sisi $\mathrm{R} / \mathrm{C}$ rasio total, pembenihan lele dumbo memiliki $\mathrm{R} / \mathrm{C}$ rasio total sebesar 1.40 yang menjelaskan bahwa tiap 1 rupiah dari biaya tunai yang dikeluarkan akan memperoleh penerimaan sebesar Rp 1.40 yang menyebabkan pendapatan tunai yang diterima adalah sebesar Rp 0.40 per satuan input biaya tunai yang dikeluarkan. Sementara untuk pembenihan lele sangkuriang memperoleh $\mathrm{R} / \mathrm{C}$ rasio tunai sebesar 1.16 sehingga pendapatan tunai yang diperoleh adalah sebesar Rp 0.16 per satuan input biaya tunai.

Hal ini mengindikasikan bahwa dari sisi $\mathrm{R} / \mathrm{C}$ rasio total pun memang pembenihan lele sangkuriang sudah efisien karena nilai $\mathrm{R} / \mathrm{C}$ rasionya lebih dari 1 , akan tetapi pembenihan lele dumbo dilihat dari $\mathrm{R} / \mathrm{C}$ rasionya lebih menguntungkan dibandingkan dengan pembenihan lele sangkuriang dikarenakan pendapatan tunai yang diperoleh pembenih lebih besar. Sehingga, baik dari R/C rasio tunai maupun total menyatakan bahwa pembenihan lele dumbo memberikan pendapatan lebih besar dibandingkan dengan pembenihan lele sangkuriang di Desa Babakan, Kecamatan Ciseeng, Kabupaten Bogor.

\section{UJI BEDA CHI-SQUARE}

Pada penelitian ini uji beda chi square digunakan untuk menguji secara statistik besaran $\mathrm{R} / \mathrm{C}$ rasio dan melihat keberagaman nilai $\mathrm{R} / \mathrm{C}$ rasio yang dihasilkan dari analisis pendapatan per individu dari usahatani pembenihan lele dumbo dan lele sangkuriang. Adapun tahapan-tahapannya yaitu :

\section{Uji Hipotesis}

Ho: Pembenihan lele dumbo dan sangkuriang tidak berbeda nyata antara $\mathrm{R} / \mathrm{C}$ tunai dan $\mathrm{R} / \mathrm{C}$ total

H1: Pembenihan lele dumbo dan sangkuriang memiliki perbedaan $\mathrm{R} / \mathrm{C}$ tunai dan $\mathrm{R} / \mathrm{C}$ total

\section{Wilayah Kritis}

$\mathrm{n}=15 \alpha=10 \%$

$\mathrm{X}^{2}$ tabel $: \mathrm{X}_{0,1 / 2(14)}^{2}$ yaitu $=23.685$

\section{Statistik Uji}

a. Statistik Uji untuk R/C tunai antara pembenihan lele dumbo dan Sangkuriang yaitu :

$$
\begin{gathered}
\mathrm{X}^{2}=\frac{(\mathrm{n}-1) \mathrm{S}^{2}}{\sigma_{0}^{2}} \\
\mathrm{X}^{2} \text { hitung }=\left((15-1) \times(0,21)^{2}\right) \quad: \\
(0,13)^{2}=36.5325
\end{gathered}
$$

b. Statistik Uji untuk R/C tunai antara pembenihan lele dumbo dan Sangkuriang yaitu :

$$
\begin{gathered}
\mathrm{X}^{2}=\frac{(\mathrm{n}-1) \mathrm{S}^{2}}{\sigma_{0}^{2}} \\
\mathrm{X}^{2} \text { hitung }=\left((15-1) \times(0,19)^{2}\right) \quad: \\
(0,12)^{2}=35.0972
\end{gathered}
$$

\section{Kesimpulan Hipotesis}

Nilai X2 hitung $\mathrm{R} / \mathrm{C}$ tunai yaitu 36.5325 dan $\mathrm{R} / \mathrm{C}$ total yaitu 35.0972 yang masing-masing lebih besar dari nilai X2 tabel sebesar 23.685 sehingga dapat dikatakan nilai $\mathrm{R} / \mathrm{C}$ rasio atas biaya tunai dan total pada pembenihan lele dumbo dan 
sangkuriang adalah berbeda secara statisitik pada taraf nyata $10 \%$.

\section{SIMPULAN DAN SARAN Simpulan}

Proporsi penerimaan benih lele terbanyak untuk pembenihan lele dumbo berada pada ukuran 7-8 cm sebesar $29,79 \%$ dari total penerimaan, sementara untuk pembenihan lele sangkuriang proporsi penerimaan terbanyak diperoleh pada benih ukuran 11-12 cm sebesar $33.58 \%$ dari total penerimaan. Namun, total penerimaan untuk semua ukuran masih lebih besar pembenihan lele sangkuriang dikarenakan penggunaan padat tebar sangkuriang yang berukuran benih 1-2 $\mathrm{cm}$ lebih banyak digunakan dibandingkan pembenihan lele dumbo

Biaya usahatani terdiri dari biaya tunai dan biaya non tunai. Jumlah total biaya pembenihan lele dumbo per hektar lebih sedikit dibandingkan total biaya pembenihan lele sangkuriang per hektarnya. Biaya tunai tersebut digunakan untuk penggunaan saprotan yang terdiri dari biaya benih dan biaya pakan, biaya pemeliharaan (booster, plastic, garam, packing, karet), biaya transportasi, biaya komunikasi, pajak lahan dan biaya tenaga kerja luar keluarga.

Biaya benih dan biaya pakan menjadi input yang yang paling berpengaruh dalam aktivitas produksi. Bila terjadi kenaikan harga, ketidaktepatan penggunaan jumlah benih dan pakan akan sangat mempengaruhi jumlah output yang dihasilkan oleh pembenih baik bagi pembenih lele dumbo maupun lele sangkuriang.
Sementara, untuk biaya non tunai terdiri dari biaya penyusutan, biaya sewa lahan, dan biaya tenaga kerja luar keluarga. Proporsi biaya tenaga kerja dalam keluarga di kedua sistem pembenihan lebih besar dibandingkan dengan untuk biaya penyusutan dan sewa lahan yaitu $68.74 \%$ dari total biaya non tunai untuk pembenihan lele dumbo dan $71.19 \%$ dari total biaya non tunai untuk pembenihan lele sangkuriang. Namun, penggunaan tenaga kerja luar keluarga (TKLK) lebih banyak dibandingkan dengan tenaga kerja dalam keluarga (TKDK) di kedua system pembenihan.

Namun dilihat dari sisi pendapatan baik tunai atapun non tunai pembenihan lele dumbo memberikan pendapatan yang lebih besar dibandingkan pembenihan lele sangkuriang di Desa Babakan, Kecamatan Ciseeng, Bogor meskipun penggunaan input benihnya lebih banyak pembenihan lele sangkuriang.

Di samping itu, dari sisi $\mathrm{R} / \mathrm{C}$ rasio baik tunai ataupun total, pembenihan lele dumbo memberikan pendapatan lebih besar dan lebih efisien dibandingkan dengan pembenihan lele sangkuriang. Sementara untuk analisis chi-square membuktikan bahwa perbedaan cara budidaya dapat mempengaruhi pendapatan sehingga antara pembenihan lele dumbo dan lele sangkuriang dapat dikatakan berbeda secara nyata.

Oleh sebab itu, untuk Desa Babakan, Kecamatan Ciseeng, Kabupaten Bogor, penggunaan benih jenis lele dumbo lebih sesuai dengan kondisi lingkungan dan lebih memberikan pendapatan yang tinggi bagi pembudidaya lele dibandingkan dengan menggunakan lele sangkuriang. 


\section{Saran}

Usahatani pembenihan lele dumbo di Desa Babakan lebih memberikan pendapatan yang tinggi bagi pembudidaya lele dibandingkan dengan lele sangkuriang. Namun, bila lele sangkuriang tetap ingin digunakan, penggunaan padat tebar benih 1-2 $\mathrm{cm}$ harus dikurangi dan disesuaikan dengan standar SOP budidaya lele yaitu 10.000 sampai 15.000 ekor benih per $300 \mathrm{~m}^{2}$.

\section{DAFTAR PUSTAKA}

Afrianto, E dan E. Liviawaty. 2005. Pakan Ikan Pembuatan, Penyimpanan, Pengujian, Pengembangan. Penerbit Kanisius. Yogyakarta.

Alawode O.O, A.O Jinad. 2014. Evaluation of Technical Efficiency of Catfish Production in Oyo State: A Case Study of Ibadan Metroplis. Journal of Emerging Trends in Educational Research and Policy Studies. 5(2): 223-231.

Beattie BR and CR Taylor. 1985. The Economics of Production. New York (USA): Wiley.

Dinas Peternakan dan Perikanan Pemerintah Kabupaten Bogor. 2012. Buku Data Perikanan Tahun 2012, Cibinong.

Debertin DL. 2002. Agricultural Production Economics. 2nd Ed. Kentucky (US): University of Kentucky

Hanafie R. 2010. Pengantar Ekonomi Pertanian. Yogyakarta (ID): CV. Andi Offset.

Hernanto F. 1996. Ilmu Usahatani. Jakarta (ID) : Penebar Swadaya
Jaja, Suryani A, Sumantadinata K. 2013. Enlargement Enterprise and Marketing of Catfish and Development Strategies at UD Sumber Rezeki Parung, West Java. Manajemen IKM. Vol 5 (1): 45-56.

[KKP] Kementerian Kelautan dan Perikanan. 2013. Volume Produksi Perikanan Indonesia [internet]. [diunduh 2014 Desember 8]. Tersedia pada http://statistik.kkp.go.id/index.php /arsip/file/37/kpda11_ok_06_v02. pdf/

Mahyuddin, Kholish. 2008. Panduan Lengkap Agribisnis Lele. Penebar Swadaya. Jakarta Olagunju FI, Adesiyan IO, Ezekiel AA (2007) Economic viability of catfish production in Oyo State, Nigeria. J.Human Ecol. 21(2): 121-124

Salvator D. 2005. Ekonomi Manajerial. Ichsan Setyo Budi, penerjemah; Palupi Wuriati, editor. Terjemahan dari: Managerial Economics. Edisi ke-5. Jakarta (ID): Salemba Empat.

[SNI] Standar Nasional Indonesia. 2000. Produksi Benih Ikan Lele Dumbo (Clarias gariepinus $\mathrm{x}$ C.fuscus) Kelas Benih Sebar Nomor 016484.4 -2000. Jakarta (ID) : SNI

Soekartawi. 2003. Teori Ekonomi Produksi. Jakarta [ID]: Raja Grafindo Persada.

Suratiyah K. 2011. Ilmu Usahatani. Jakarta (ID) : Penebar Swadaya

Tenaya, I M. N.2010. Metode Kuantitatif dan Kualitatif Agribisnis. Bahan Kuliah. Program Magister Manajemen Agribisnis. Laboratorium Statistika. Universitas Udayana. 2010. 
Ugwumba COA. 2011. Analysis of

Catfish Farming System and Its Impact on Net Farm Income in Anambra State, Nigeria. ARPN Journal of Agricultural and Biological Science. Vol 6 (2): 2630 
Lampiran 1. Produksi Perikanan Budidaya Air Tawar Sistem Kolam di Indonesia menurut Komoditas Utama Tahun 2009-2012 (dalam satuan ton)

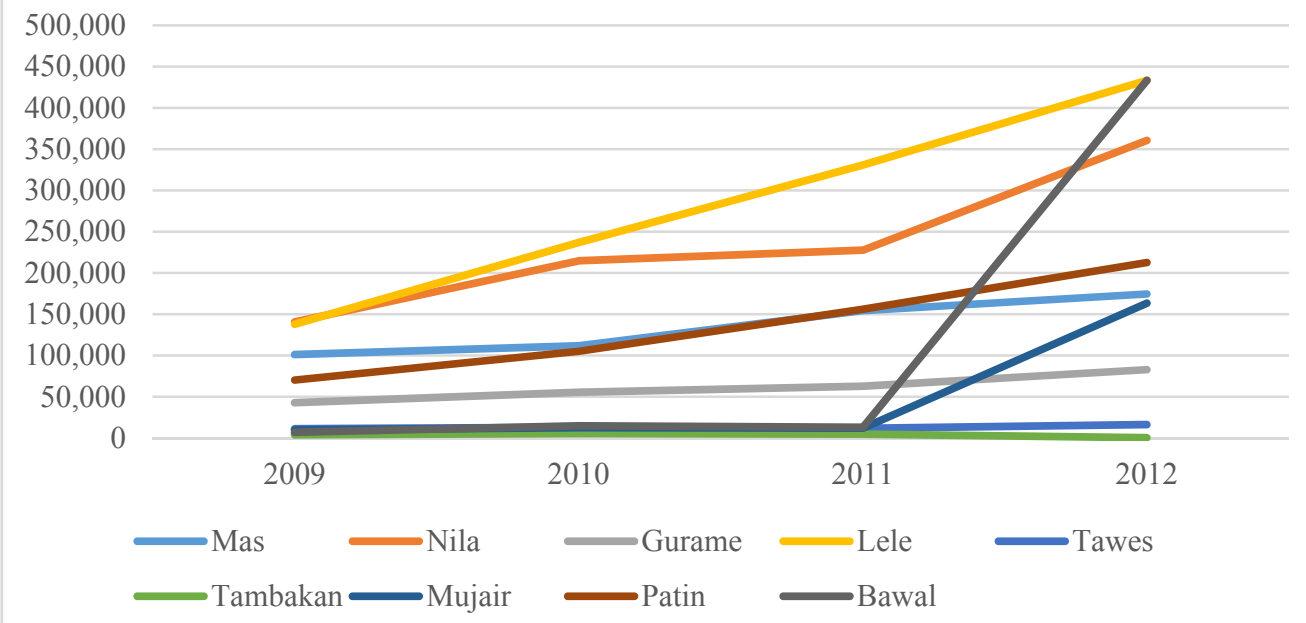

Lampiran 2. Karakteristik Lele Sangkuriang dan Lele Dumbo

Deskripsi

Kematangan gonad pertama

Fekunditas (butir telur/Kg induk)

Diameter telur (mm)

Lamanya kantong telur terserap suhu

23-24 celcius (hari)

Derajat penetasan telur $(\%)$

Sifat larva

Kelangsungan hidup larva (\%)

Pakan alami larva
Karakter Reproduksi Lele Sangkuriang Lele Dumbo $8-9$ bulan $4-5$ bulan

$40.000-60.000$

$20.000-30.000$

$1,1-1,4$

$4-5$

$1,1-1,4$

$4-5$

$>90$

$>80$

Tidak kanibal

Tidak kanibal

90-95

90-95

Moina sp, Daphia sp, Moina sp, Daphia Tubifex sp $\mathrm{sp}$, Tubifex sp 
Lampiran 3. Jumlah Ikan Konsumsi Ikan Lele per Kapita per Tahun $\mathrm{Kg} / \mathrm{kapita}$

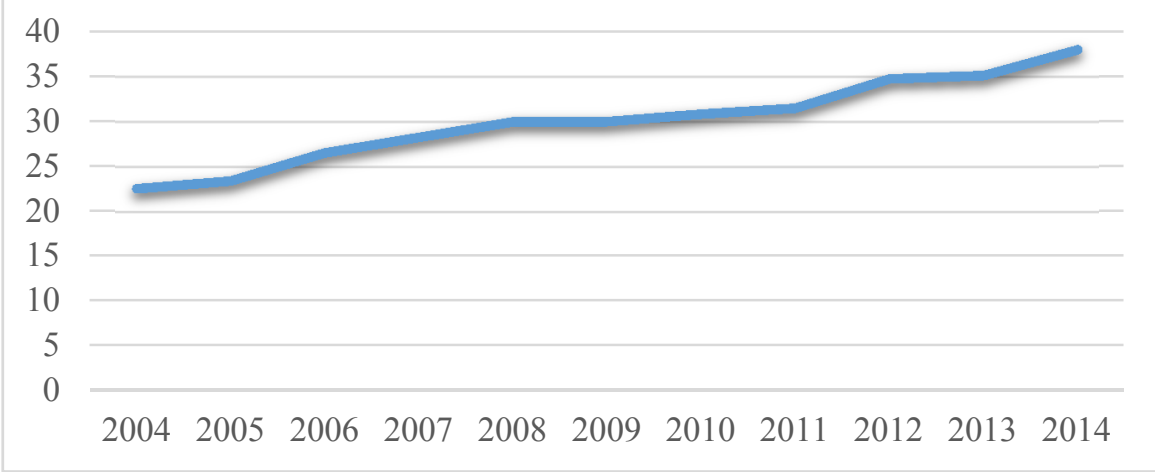




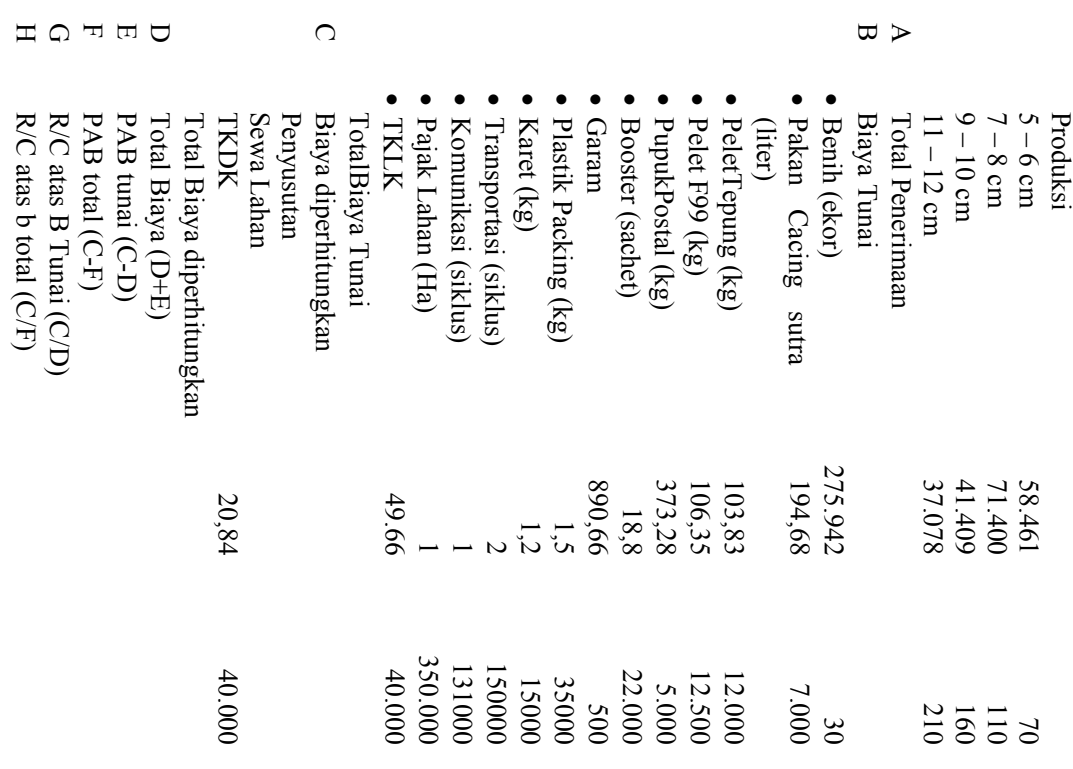

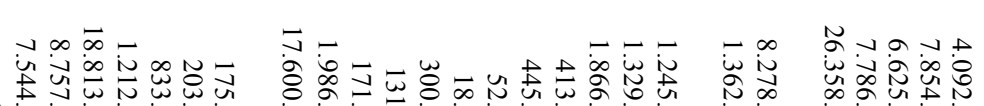

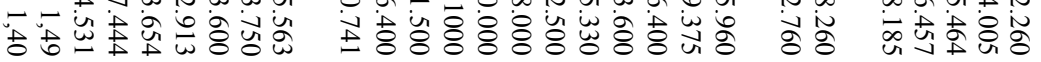

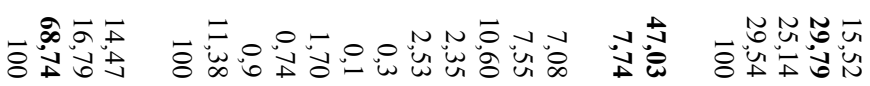

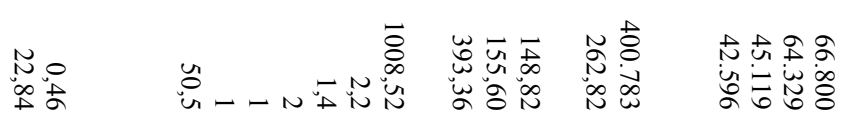

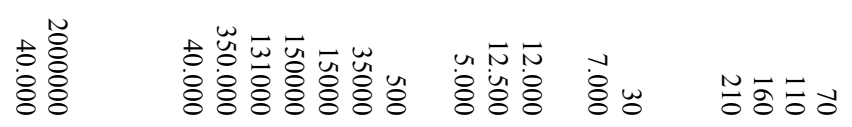

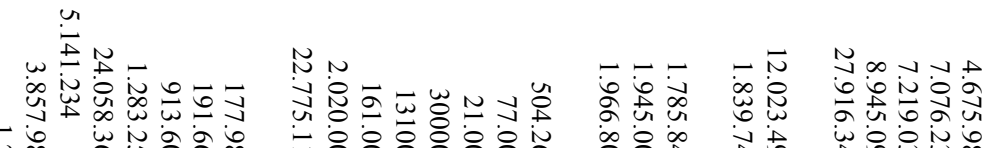

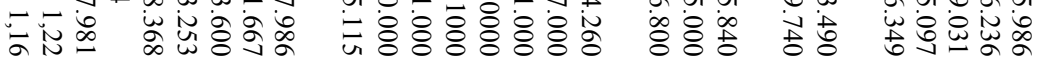
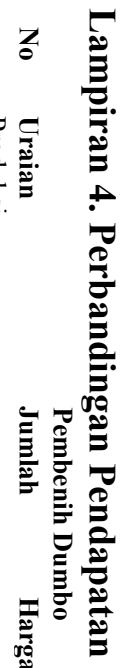

증

赵 